\title{
In vitro antimicrobial activity of aqueous extracts from Lentinula edodes isolates against Colletotrichum sublineolum and Xanthomonas axonopodis pv. passiflorae
}

\author{
Nivea Maria Tonucci-Zanardo ${ }^{1}$, Sérgio Florentino Pascholati ${ }^{1}$, Robson Marcelo Di Piero ${ }^{2}$
}

\author{
${ }^{1}$ Universidade de São Paulo, Escola Superior de Agricultura Luiz de Queiroz, Caixa Postal 9, CEP 13418-900, Piracicaba, SP, Brazil. \\ ${ }^{2}$ Universidade Federal de Santa Catarina' Caixa Postal 476, CEP 88040-900, Florianópolis, SC, Brazil. \\ Autor para correspondência: Sérgio Florentino Pascholati (sfpascho@usp.br) \\ Data de chegada: 01/04/2014. Aceito para publicação em: 19/12/2014.
}

$10.1590 / 0100-5405 / 1995$

\begin{abstract}
Tonucci-Zanardo, N.M.; Pascholati, S. F., Di Piero, R.M. In vitro antimicrobial activity of aqueous extracts from Lentinula edodes isolates against Colletotrichum sublineolum and Xanthomonas axonopodis pv. passifloraeSumma Phytopathologica, v.41, n.1, p.13-20, 2015.

The aim of this study was to evaluate the antimicrobial activity of aqueous extracts from fruiting bodies of different isolates of Lentinula edodes on the pathogens Colletotrichum sublineolum, the causal agent of anthracnose in sorghum, and Xanthomonas axonopodis pv. passiflorae, the causal agent of bacterial spot in passion fruit. Results showed that the aqueous extracts from isolates LE JAB-K and LE 95/01 significantly reduced C. sublineolum spore germination, while the isolate LE 96/22 was the only one to inhibit the pathogen mycelial growth. However, all $L$. edodes isolates showed inhibitory effect on C. sublineolum appressorium formation. Regarding $X$. axonopodis pv. passiflorae, the aqueous extracts

from all L. edodes isolates significantly reduced the in vitro multiplication of the bacterium. However, antimicrobial activity was lost when the extracts were autoclaved, demonstrating their thermolabile property. The aqueous extract from isolate LE 96/22 was also partially purified by anion exchange chromatography and fraction $\mathrm{V}$ exhibited high inhibitory activity on the in vitro mycelial growth of C. sublineolum, while the multiplication of $X$. axonopodis pv. passiflorae was inhibited by fractions IV, V and VII. Thus, L. edodes isolates were shown to produce compounds exhibiting antifungal and antibacterial activities against phytopathogens, which are mainly concentrated in fraction V.
\end{abstract}

Additional keywords: mushroom, anthracnose, bacterial spot, sorghum, passion fruit

\section{RESUMO}

Tonucci-Zanardo, N.M.; Pascholati, S. F., Di Piero, R.M. Atividade antimicrobiana in vitro de extratos aquosos de isolados de L. edodes contra Colletotrichum sublineolum e Xanthomonas axonopodis pv. passiflorae. Summa Phytopathologica, v.41, n.1, p.13-20, 2015.

O objetivo deste estudo foi avaliar a atividade antimicrobiana dos extratos aquosos de corpos de frutificação de diferentes isolados de Lentinula edodes sobre os patógenos Colletotrichum sublineolum, agente causal da antracnose em sorgo e em Xanthomonas axonopodis pv. passiflorae, agente causal da mancha bacteriana em maracujá. Os resultados mostraram que os extratos aquosos dos isolados LE JAB - K e LE 95/ 01 reduziram significativamente a germinação de esporos de C. sublineolum, enquanto que o isolado LE 96/22 foi o único a inibir o crescimento micelial do patógeno. No entanto, todos os isolados de L. edodes mostraram efeito inibitório na formação de apressórios por C. sublineolum. Quanto a X. axonopodis pv. passiflorae, os extratos aquosos obtidos de todos os isolados do cogumelo reduziram significativamente a multiplicação in vitro da bactéria. No entanto, a atividade antimicrobiana foi perdida quando os extratos foram autoclavado demonstrando assim a propriedade termolábil dos mesmos. O extrato aquoso do isolado LE 96/22 também foi parcialmente purificado por cromatografia de troca aniônica e a fração $\mathrm{V}$ exibiu elevada atividade inibitória sobre o crescimento micelial in vitro de C. sublineolum, enquanto que a multiplicação de $X$. axonopodis pv. passiflorae foi inibida pelas frações IV, V e VII. Desta forma, demonstrou-se que os isolados de L. edodes produzem compostos que apresentam atividade antifúngica e antibacteriana contra fitopatógenos, que estão principalmente concentrados na fração $\mathrm{V}$.

Palavras-chave adicionais: cogumelo, antracnose, mancha bacteriana, sorgo, macarujá.

Lentinus edodes (Berk.) Pegler (= Lentinula edodes (Berk.) Singer) or shiitake, as it is popularly known, is a basidiomycete with nutritional, therapeutic and medicinal properties. L. edodes contains proteins, lipids (primarily linoleic acid), carbohydrates, fibers, minerals, vitamins B1, B2 and C, and ergosterol (25). Furthermore, researchers have shown that $L$. edodes produces several compounds with antithrombotic and anticholesterol effects, besides antifungal, antibacterial and antiviral activities (9). Several studies demonstrated the therapeutic activity of polysaccharides (glucans and heterogalactans) and glucanproteins present in the vegetative mycelium or fruiting bodies of the fungus (14). The lentinan, a $\beta$-( $1 \rightarrow 3)$-D-glucan extracted from $L$. edodes, showed antitumor, antibacterial, antiviral and anticlotting activities (7).

The cotinellin isolated from $L$. edodes exhibited antibiotic activity against the pathogens Candida albicans, Staphylococcus aureus and Bacillus subtilis (1). A compound isolated from the fruiting body of L. edodes had fungistatic effect against $C$. albicans (15). Lenthionine, a substance obtained from the mycelial culture filtrate of L. edodes, exhibited inhibitory activity on Streptococcus pyogenes, S. aureus, 
B. megaterium and C. albicans (5). In addition, there are reports demonstrating the production of metabolites by $L$. edodes with antibiotic activity against several phytopathogens (23), and disease control was demonstrated in several crops such as sorghum, passion fruit (19) and cucumber (3). The mycelial culture filtrate of L. edodes was also observed to cause inhibitory effects on Helminthosporium spp. and $H$. euphorbiae (22). The leached of mycelium from $L$. edodes also presented inhibitory activity on several species of phytopathogenic bacteria such as Pseudomonas syringae pv. glycinea, P. syringae pv. tabaci, Xanthomonas campestris pv. glycines and Erwinia amylovora (16).

The fungus Colletotrichum sublineolum (P. Henn. Kabat et Bub.) causes anthracnose, one of the main diseases of sorghum crop in Brazil. It can cause losses of up to $88 \%$ in grain yield and drastically affect the quality of the produced seed. The pathogen infects leaves, stems, flowers and seeds of sorghum at any age. Symptoms on the leaves begin with small round lesions of staining purple that evolve and result in a large necrotic leaf area (17).

The bacterial spot in yellow passion fruit plants is caused by Xanthomonas axonopodis pv. passiflorae (Pereira) Dye. The bacterium is rod-shaped, $0.5 \times 1.5 \mu \mathrm{m}$, Gram-negative and aerobic, which does not produce spores or capsules and has a polar flagellum. It is important in Brazil due to its occurrence in all producing regions, the high susceptibility of economically important cultivars and the difficulty to control it (4).

Chemical control has been one of the main attempts to reduce the losses caused by these diseases. Problems associated with the selection of pathogen isolates resistant to fungicides (2) and the public general perception of the potential impact of traditional control practices on the health and the environment led to an increased demand for residue-free chemical products. Consequently, both farmers and researchers started to consider the use of alternative methods to control diseases (21). Therefore, in the present study, we investigated the in vitro antimicrobial effects of aqueous extracts from fruiting bodies of four isolates of $L$. edodes and their partially purified fractions against $C$. sublineolum and $X$. axonopodis pv. passiflorae.

\section{MATERIALS AND METHODS}

\section{Phytopathogens}

C. sublineolum was isolated from symptomatic leaves of sorghum and grown in oat-agar medium at $21^{\circ} \mathrm{C}$, under near U.V. light (10). $X$. axonopodis pv. passiflorae was isolated from the leaves of passion fruit plants (Passiflora edulis f. flavicarpa) showing systemic symptoms of the disease based on a modification of the method of Malavolta et al. (13). The leaves were cut into small pieces and received a drop of distilled water to observe the bacterial run under an optical microscope. The bacteria were transferred to nutrient agar medium and maintained at $28^{\circ} \mathrm{C}$ in the dark.

Obtaining aqueous extracts from fruiting bodies of $L$. edodes

The fruiting bodies were obtained after the mushroom cultivation in Eucalyptus grandis and E. saligna logs kept under a shaded house at the Department of Plant Production, Faculty of Agricultural Sciences/ UNESP/Botucatu/SP $(18,20)$.

The dehydrated powder from fruiting bodies of $L$. edodes isolates LE JAB-K, LE 95/01, LE 96/17 and LE 96/22 received sterile distilled water ( $1 \mathrm{~g}$ powder in $14 \mathrm{~mL}$ of distilled water). The mixture was incubated at $4{ }^{\circ} \mathrm{C}$ for $24 \mathrm{~h}$. Afterwards, the extract was filtered through
Whatman \# 4 filter paper by using a Buchner funnel, centrifuged $\left(20.000 \mathrm{~g} / 25 \mathrm{~min}\right.$ at $\left.4{ }^{\circ} \mathrm{C}\right)$ and the supernatant was filtered through a Millipore membrane $(0.2 \mu \mathrm{m})$ and stored at $5{ }^{\circ} \mathrm{C}$ until used. Depending on the experimental requirements, part of the aqueous extract was autoclaved at $121{ }^{\circ} \mathrm{C}$ for $15 \mathrm{~min}$ and stored in a refrigerator.

Effect of the aqueous extracts on conidial germination, appressorium formation and mycelial growth of $\boldsymbol{C}$. sublineolum

Colletotrichum sublineolum was isolated from symptomatic leaves of sorghum. Segments of plant tissue (approximately $8 \mathrm{~mm}^{2}$ ) were placed in a solution of commercial sodium hypochlorite (three parts water to one part hypochlorite; $\mathrm{v} / \mathrm{v}$ ). After $5 \mathrm{~min}$, the tissue was washed three times in distilled water to remove excess hypochlorite. Then, five segments of the tissue were placed on the surface of the water-agar culture medium inside Petri dishes and kept at $23^{\circ} \mathrm{C}$ under continuous light for 10 days. After this period, mycelial disks were transferred to oatmeal agar medium to obtain pure cultures of the fungus.

ELISA plates were used to evaluate spore germination and appressorium formation of C. sublineolum. Each well (eight per treatment) received $40 \mu \mathrm{L}$ of conidial suspension ( $10^{5}$ conidia per $\mathrm{mL}$ ) and $40 \mu \mathrm{L}$ of aqueous extract. L. edodes aqueous extracts were used at the final concentrations of $50 \%(\mathrm{v} / \mathrm{v})$. Control consisted of sterile distilled water plus conidial suspension, and eight replicates for each treatment were evaluated. The plates were maintained in the dark at $23{ }^{\circ} \mathrm{C}$ for $20 \mathrm{~h}$ and, after that period, $20 \mu \mathrm{L}$ of lactophenol were added to each well to stop spore germination. Spore germination and appressorium formation were evaluated by using an optical microscope. At least 100 spores were counted per replicate.

To evaluate the effect of aqueous extracts on the mycelial growth of C. sublineolum, $0.5 \mathrm{~mL}$ of the extracts were added to the surface of potato dextrose agar (PDA) in Petri dishes and spread with the aid of a Drigalsky loop. The control plate received sterile distilled water on the surface of the PDA medium in Petri dishes instead of aqueous extracts from the isolates. After $24 \mathrm{~h}$, a $6 \mathrm{~mm}$-diameter agar plug containing mycelium of $C$. sublineolum was transferred to the dishes (six Petri dishes per treatment) which were maintained under fluorescent light at $26^{\circ} \mathrm{C}$. At every three days, the mycelial growth of the pathogen was measured by calculating the average of two diameters of colonies at right angles for each plate. In this experiment, the isolate LE JAB-K was not used because of the low availability of the fruiting body powder.

\section{Effects of the aqueous extracts on $X$. axonopodis pv. passiflorae multiplication}

In plastic conical test tubes, the aqueous extracts from fruiting bodies (original concentration of $1 \mathrm{~g}$ powder in $14 \mathrm{~mL}$ of distilled water) of the different isolates were mixed with distilled water to obtain the final concentrations of $5,10,15$ or $20 \%(\mathrm{v} / \mathrm{v})$. Control treatment was represented by water. Then, the tubes showing volume of $9 \mathrm{~mL}$ of extracts received $1 \mathrm{~mL}$ of the bacterial suspension adjusted to $80 \%$ transmittance at $680 \mathrm{~nm}$ in a spectrophotometer. The suspensions were homogenized and incubated in the darkness for $24 \mathrm{~h}$ at $30^{\circ} \mathrm{C}$. After incubation, $250 \mu \mathrm{L}$ of the suspensions were spread on nutrient agar medium, and the plates (five per treatment) were maintained at $30^{\circ} \mathrm{C}$ in the darkness for 72 hours. After 3 days, bacterial growth was evaluated by adding $20 \mathrm{~mL}$ of distilled water to each plate and the transmittance of bacterial suspensions was determined at $680 \mathrm{~nm}$. Transmittance values were transformed into absorbance values to express bacterial growth. In another assay, the aqueous extracts at $20 \%(\mathrm{v} / \mathrm{v})$ were autoclaved during $15 \mathrm{~min}$ at $121^{\circ} \mathrm{C}$. These autoclaved aqueous extracts were used as described above, but the isolate LE 96/17 was not used because it 
was no longer available.

Partial purification of the fruiting body fractions by anion exchange chromatography

A sample $(75 \mathrm{~mL})$ of the aqueous extract from isolate LE 96/22, containing $4.6 \mathrm{mg}$ of protein and $1.583 \mathrm{mg}$ of carbohydrate, was lyophilized, resuspended in $5 \mathrm{~mL}$ distilled water and filtered through a Millipore membrane $(0.2 \mu \mathrm{m})$. The sample was subjected to anion exchange chromatography (AEC) in a column $(2.5 \times 15 \mathrm{~cm})$ filled with DEAE-Cellulose equilibrated with $25 \mathrm{mM}$ sodium phosphate buffer $(\mathrm{pH}$ 6.0 ). The unbound compounds were eluted with the buffer at a flow rate of $2.5 \mathrm{~mL} \cdot \mathrm{min}^{-1}$, while the bounded compounds were eluted by using a linear gradient of $\mathrm{NaCl}$ ( 0 to $1 \mathrm{M}$ ). The collected fractions were pooled according to their profiles at $280 \mathrm{~nm}$, dialyzed in distilled water and concentrated to $9 \mathrm{~mL}$ with polyethylene glycol 20,000. The fractions were used for the bioassays with $C$. sublineolum and $X$. axonopodis.

Effects of fractions obtained through AEC on $C$. sublineolum and $X$. axonopodis

The experiment regarding conidial germination and appressorium formation was performed by using Elisa plates, where each well (eight per treatment) received $40 \mu \mathrm{l}$ of spore suspensions of $C$. sublineolum $\left(10^{5}\right.$ spores $\left.\mathrm{mL}^{-1}\right)$ and $40 \mu \mathrm{l}$ of the aqueous fractions from isolate LE $96 / 22$ and were kept at $26^{\circ} \mathrm{C}$ in the absence of light for $20 \mathrm{~h}$. After this period, $20 \mu \mathrm{L}$ of lactophenol were added to each well to stop spore germination. The spore germination and the appressorium formation were evaluated by using an optical microscope, and at least 100 spores were counted per replicate.

To evaluate the effect on mycelial growth, the fractions obtained by AEC were filtered through Millipore filters $(0.2 \mu \mathrm{m})$, and $100 \mu \mathrm{L}$ aliquots were spread onto PDA medium inside $5.0-\mathrm{cm}$ diameter Petri dishes. After $24 \mathrm{~h}$, the dishes received a $0.3-\mathrm{cm}$ diameter agar plug with mycelium of $C$. sublineolum and were kept at $26{ }^{\circ} \mathrm{C}$ under constant fluorescent light. The diameter of the mycelial growth of colonies was evaluated at every three days based on the average between two opposite measurements until the colony in the control plates reached the borders. Each treatment consisted of five replicates.

To evaluate the effect of fractions on $X$. axonopodis pv. passiflorae, test tubes containing $0.9 \mathrm{~mL}$ of each fraction received $0.1 \mathrm{~mL}$ of the bacterial suspension with $80 \%$ transmittance at $680 \mathrm{~nm}$. Control treatment was represented by water. The tubes were maintained in the darkness during $24 \mathrm{~h}$ at $30^{\circ} \mathrm{C}$. Afterwards, aliquots of $200 \mu \mathrm{l}$ of each tube were spread onto nutrient agar medium and the plates maintained in the darkness at $30{ }^{\circ} \mathrm{C}$. After 2 days, each plate received $20 \mathrm{~mL}$ distilled water and the transmittance of the bacterial suspension was determined at $680 \mathrm{~nm}$ in a spectrophotometer. The transmittance values were transformed into absorbance to express the bacterial growth. Experimental design was completely randomized, with five replicates, where each Petri dish was considered an experimental unit. Data were subjected to analysis of variance and means were compared by using Tukey's test.

\section{RESULTS AND DISCUSSION}

The fruiting body and the mycelium of $L$. edodes have compounds with antimicrobial activity. In this study, we observed the in vitro inhibitory effects of aqueous extracts from fruiting bodies of $L$. edodes on spore germination, appressorium formation and mycelial growth of $C$. sublineolum, as well as on the multiplication of $X$. axonopodis pv. passiflorae.

C. sublineolum spore germination was significantly inhibited by the aqueous extracts from isolates LE JAB-K and LE 95/01, LE 96/17, but not by the extract from isolate LE 96/22 (Figure 1). In contrast, the aqueous extracts from all isolates significantly reduced $C$. sublineolum appressorium formation (Figure 2), and only the aqueous extract from isolate LE 96/22 reduced mycelial growth (Figure 3). Maki (12) also observed differences in the antimicrobial activity among different isolates of $L$. edodes against $C$. albicans. Similar effects were also observed for aqueous extracts from fruiting bodies of $L$.

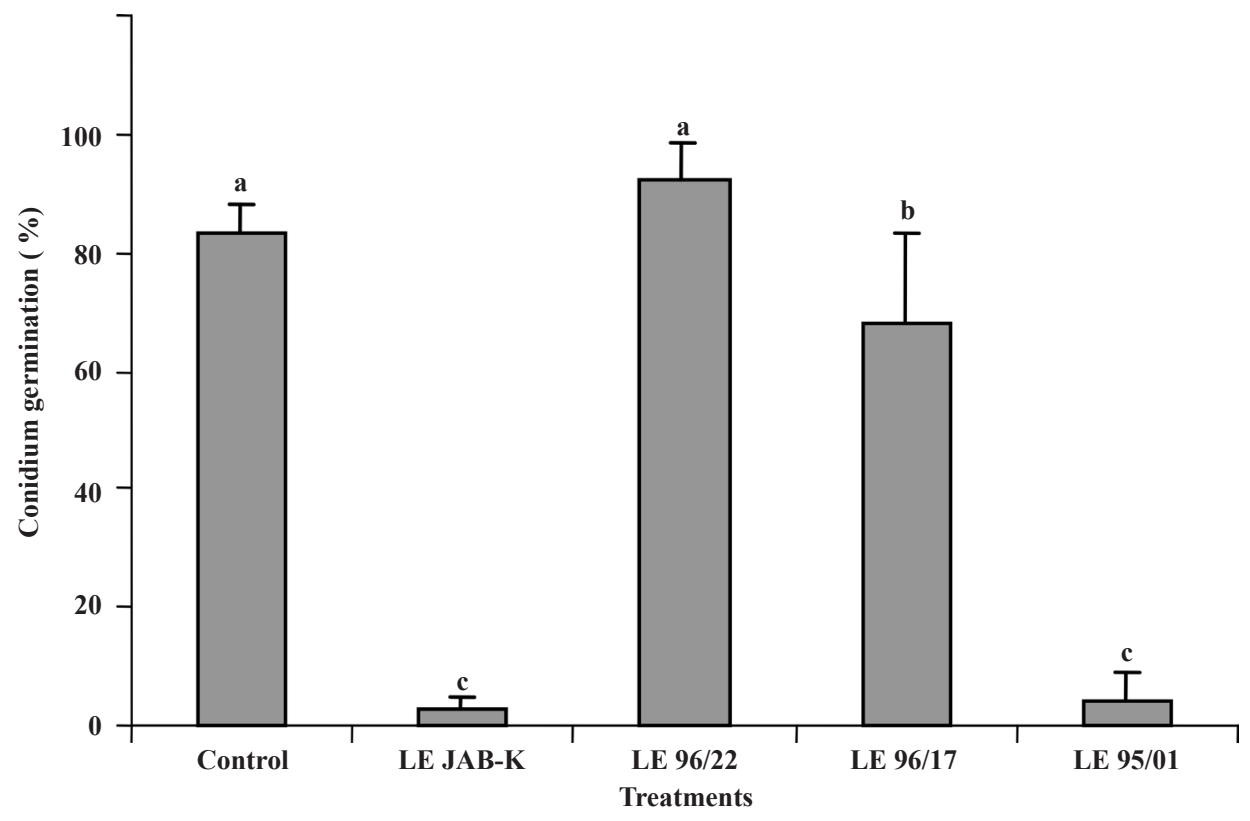

Figure 1. Effects of aqueous extracts from fruiting bodies of the isolates LE JAB-K, LE 96/22, LE 96/17 and LE 95/01 of Lentinula edodes on conidium germination of Colletotrichum sublineolum. Values are the means of three replicates $( \pm \mathrm{SD})$. Means followed by the same letter do not differ according to Tukey's test at 5\%. 


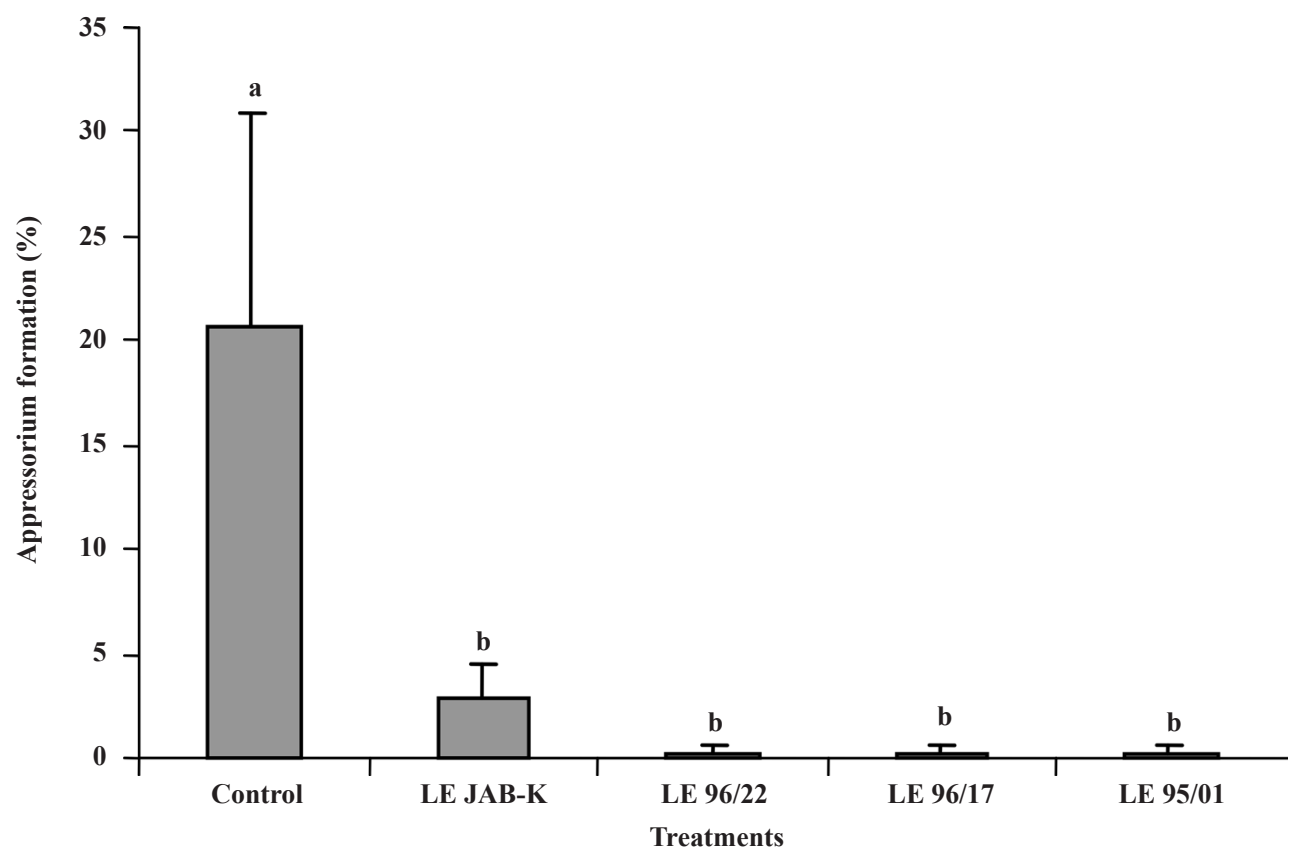

Figure 2. Effects of aqueous extracts from fruiting bodies of the isolates LE JAB-K, LE 96/22, LE 96/17 and LE 95/01 of Lentinula edodes on appressorium formation of Colletotrichum sublineolum. Values are the means of three replicates $( \pm \mathrm{SD})$. Means followed by the same letter do not differ according to Tukey's test at 5\%.

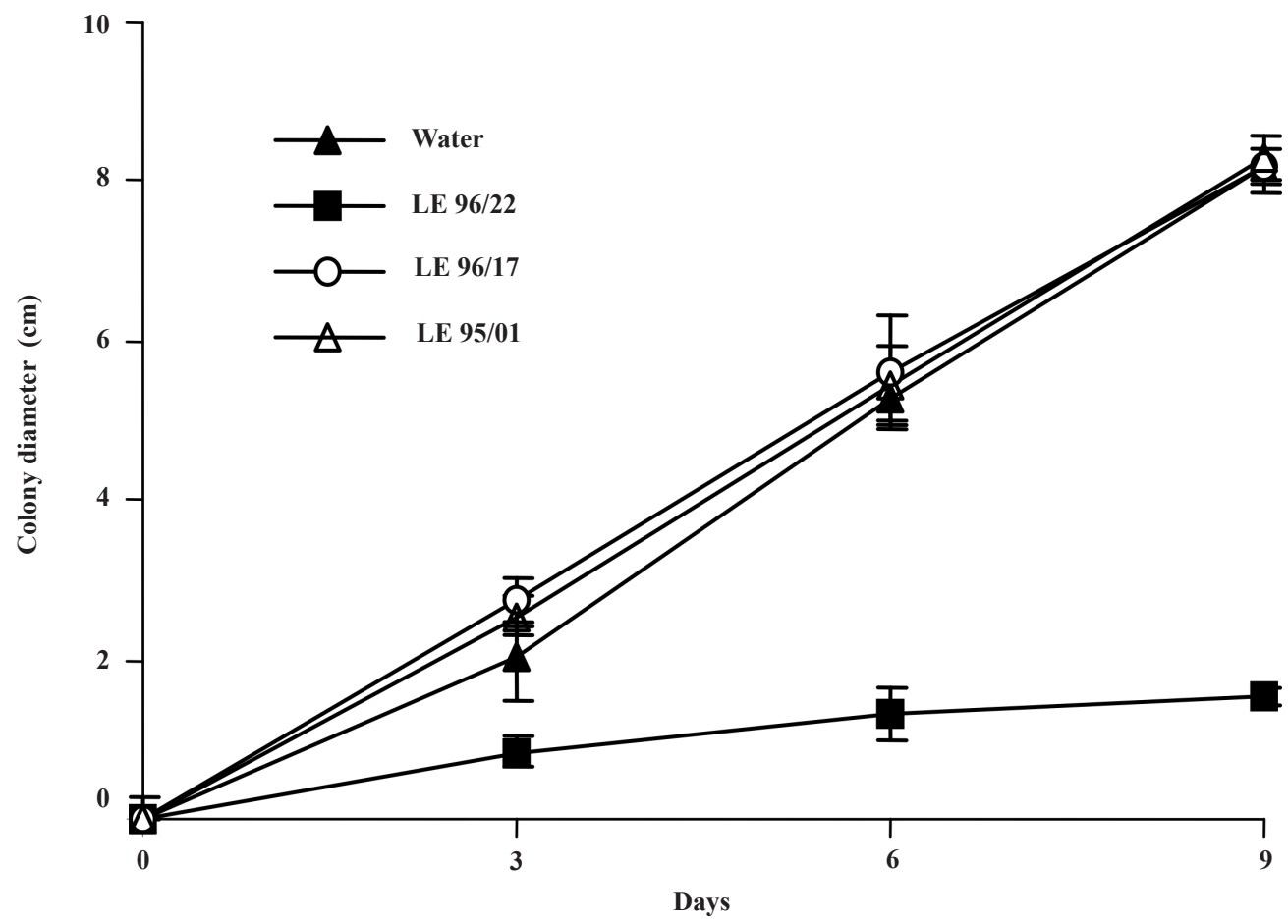

Figure 3. Effects of aqueous extracts from fruiting bodies of the isolates LE 96/22, LE 96/17 and LE 95/01 of Lentinula edodes on mycelial growth of Colletotrichum sublineolum. Values are the means of six replicates $( \pm \mathrm{SD})$.

edodes, isolate "Piracicaba", which reduced in vitro spore germination, appressorium formation and mycelial growth of C. sublineolum (19). The appressorium is an important fungal structure during the process of penetration through the leaf surface; therefore, inhibition of spore germination and mainly appressorium formation is an important measure to control plant diseases (11).

Since isolate LE 96/22 was capable of inhibiting C. sublineolum mycelial growth and appressorium formation, it was subjected to anion exchange chromatography to separate the compounds exhibiting inhibitory activity (Figure 4). Peak V reduced the mycelial growth of C. sublineolum, but peaks I, II, III, IV and VII did not show any inhibitory effects (Figure 5). Similar results were obtained by using aqueous extracts from fruiting bodies of isolates LE 95/01 and LE 96/22 of L. edodes, which stimulated the germination of Colletotrichum 


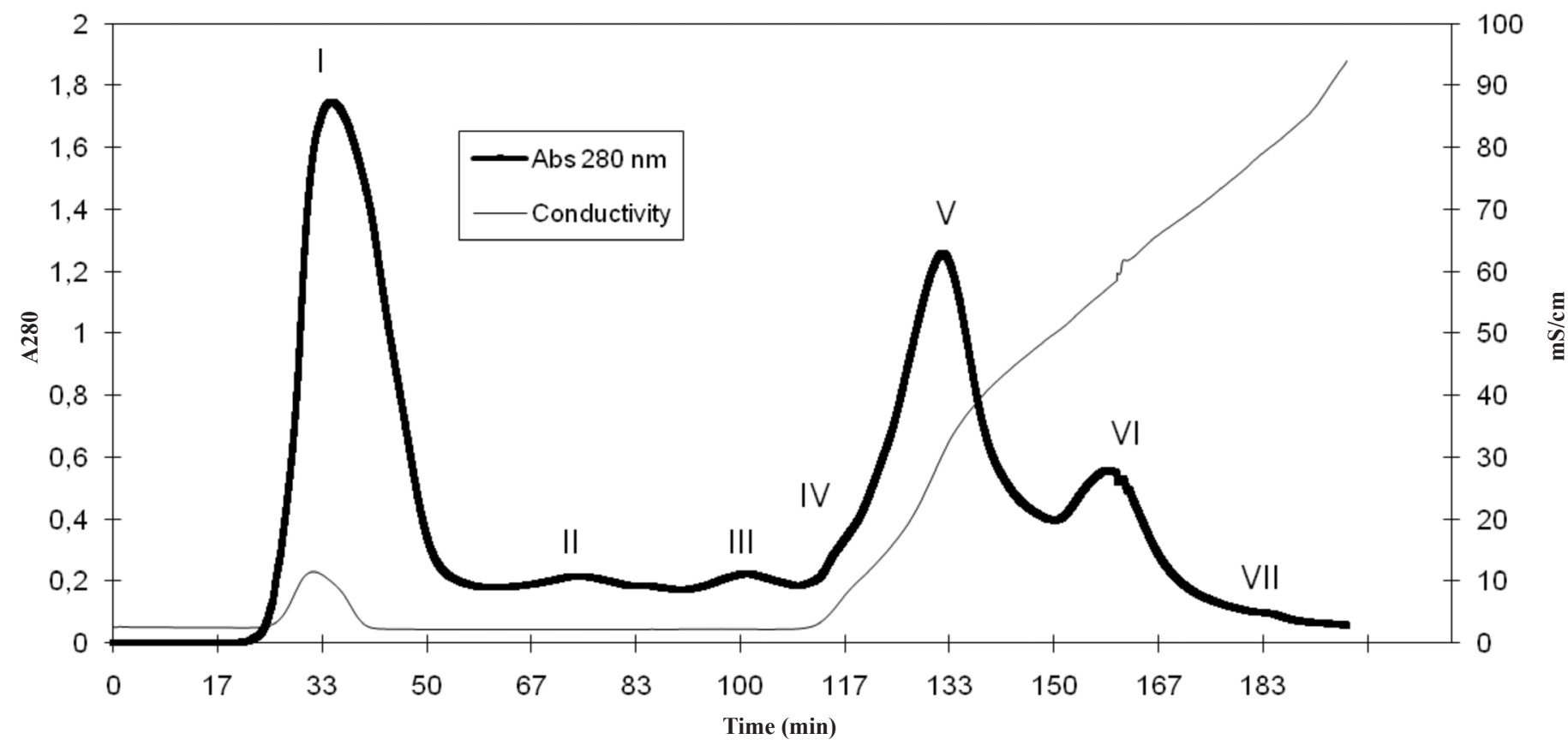

Figure 4. Anion exchange chromatography of crude aqueous extract from isolate LE 96/22 of Lentinula edodes. The chromatography was performed in column filled with DEAE-Cellulose equilibrated with $25 \mathrm{mM}$ phosphate buffer ( $\mathrm{pH} 6.0$ ), at a flow rate of $2.5 \mathrm{~mL}^{\mathrm{min}}{ }^{-1}$, and the bounded material was eluted with a linear gradient of $\mathrm{NaCl}(0$ to $1 \mathrm{M})$ in the same buffer. The fractions were pooled as peaks I, II, III, IV, V, VI and VII.

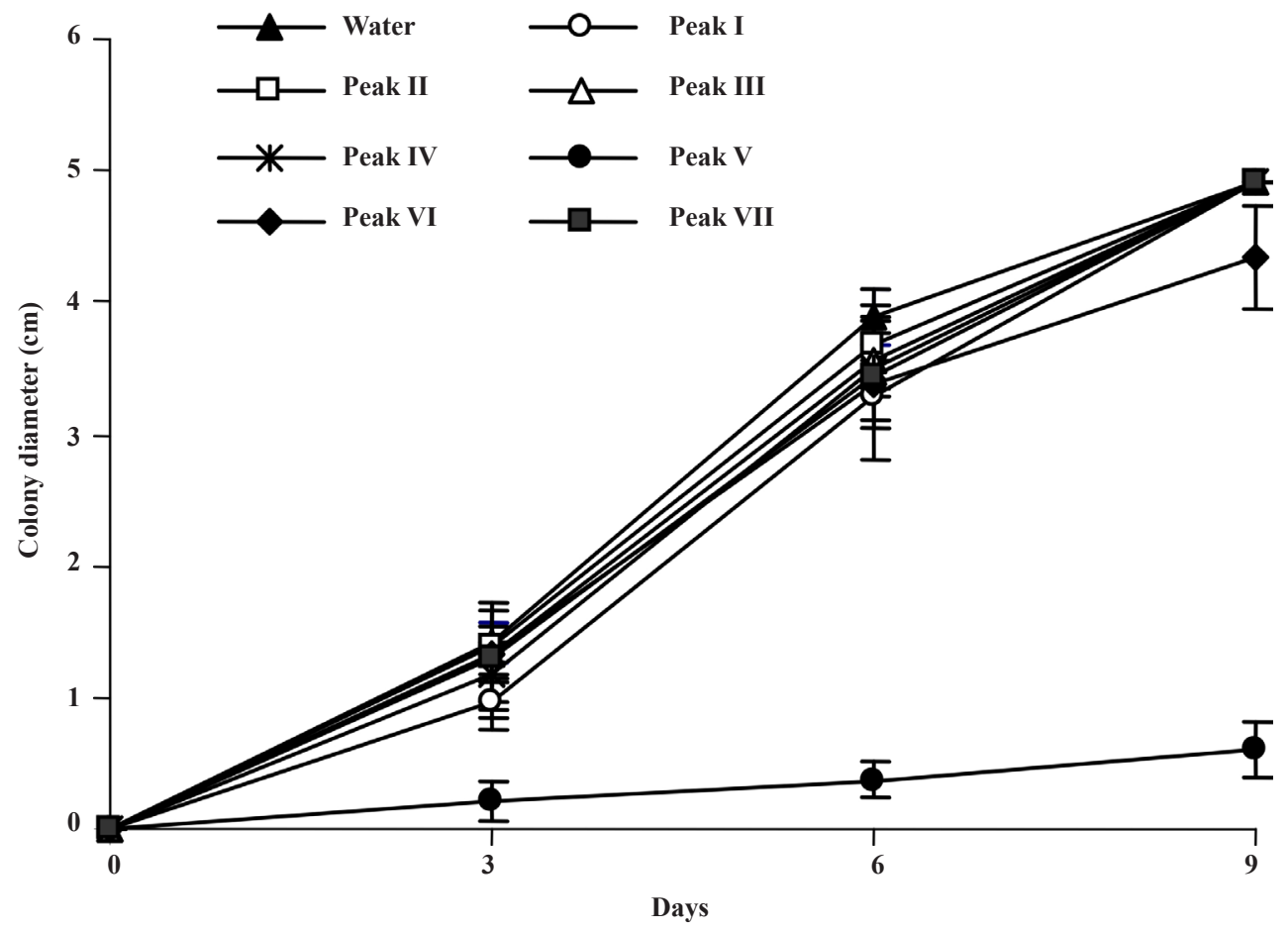

Figure 5. Effect of the pooled fractions of Lentinula edodes (isolate LE 96/22), obtained by anion exchange chromatography, on the mycelial growth of Colletotrichum sublineolum. The bars represent the standard deviation of the means. Values are the means of five replicates ( $\pm \mathrm{SD})$.

lagenarium conidia (3). The fractions obtained after AEC did not show any inhibitory effects on appressorium formation when compared to the crude aqueous extract from isolate LE 96/22 (data not shown). Activity loss after AEC can be explained by the low recovery of bioactive components from the extract due to the sample preparation conditions.

$X$. axonopodis multiplication was significantly reduced by all aqueous extracts (Figure 6). The antibiotic effect of $L$. edodes on $X$. axonopodis increased as the concentration of the aqueous extracts 


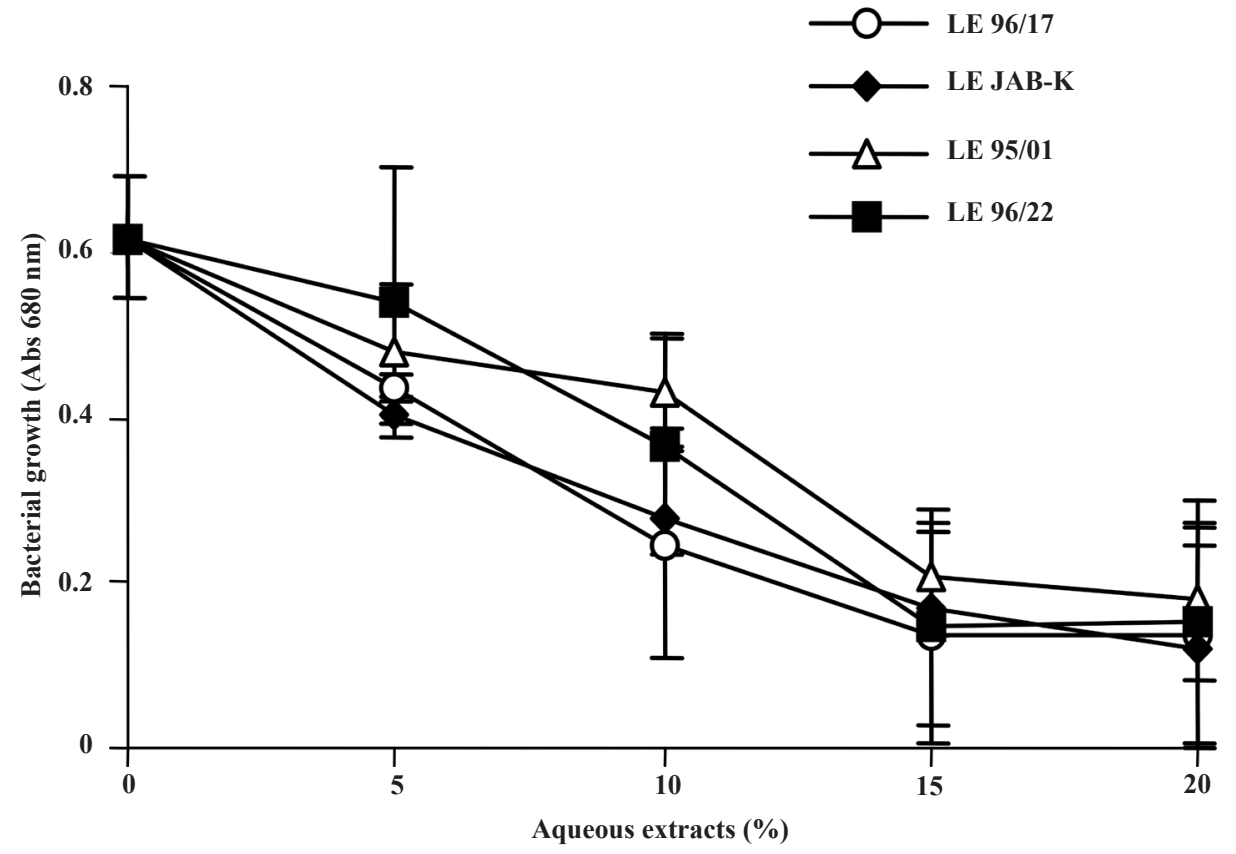

Figure 6. Effects of aqueous extracts from fruiting bodies of Lentinula edodes, at different concentrations, on the in vitro multiplication of Xanthomonas axonopodis pv. passiflorae. Values are the means of five replicates $( \pm \mathrm{SD})$. Significant effect of concentration was observed based on the F test at $5 \%$

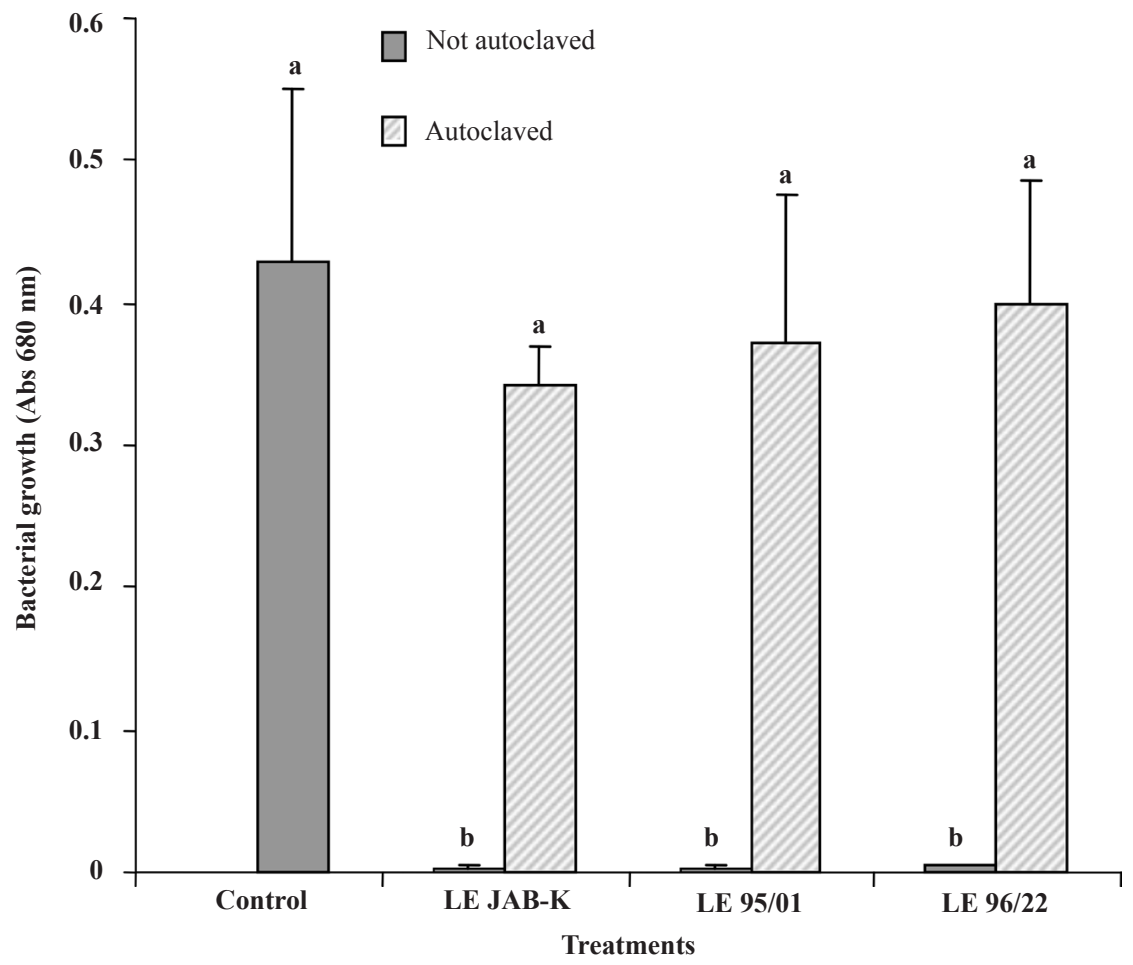

Figure 7. Effect of autoclaving the aqueous extracts (20\%) from fruiting bodies of the isolates LE JAB-K, LE 95/01 and LE 96/22 of Lentinula edodes on the in vitro multiplication of Xanthomonas axonopodis pv. passiflorae. Values are the means of three replicates ( $\pm \mathrm{SD})$. Means followed by the same letter do not differ according to Tukey's test at $5 \%$

increased up to $15 \%$. Piccinin (19) reported that the aqueous extracts from the fruiting body of $L$. edodes, isolate "Piracicaba", exhibited a bacteriostatic effect on $X$. axonopodis, while the aqueous extract from the stipe exhibited a bactericidal effect.

The aqueous extracts from fruiting bodies that were subjected to autoclaving lost their inhibitory activities on bacterial multiplication
(Figure 7). This indicates that those extracts have bioactive substances which are thermolabile. According to Hirasawa (6), the aqueous extract from $L$. edodes was thermolabile when heated up to $60^{\circ} \mathrm{C}$ for $30 \mathrm{~min}$, reducing by $60 \%$ its antibacterial activity against Streptococcus mutans and Prevotella intermedia, whereas heating of up to $100{ }^{\circ} \mathrm{C}$ for $5 \mathrm{~min}$ led to complete loss of its antibiotic activity. On the other hand, $L$. 


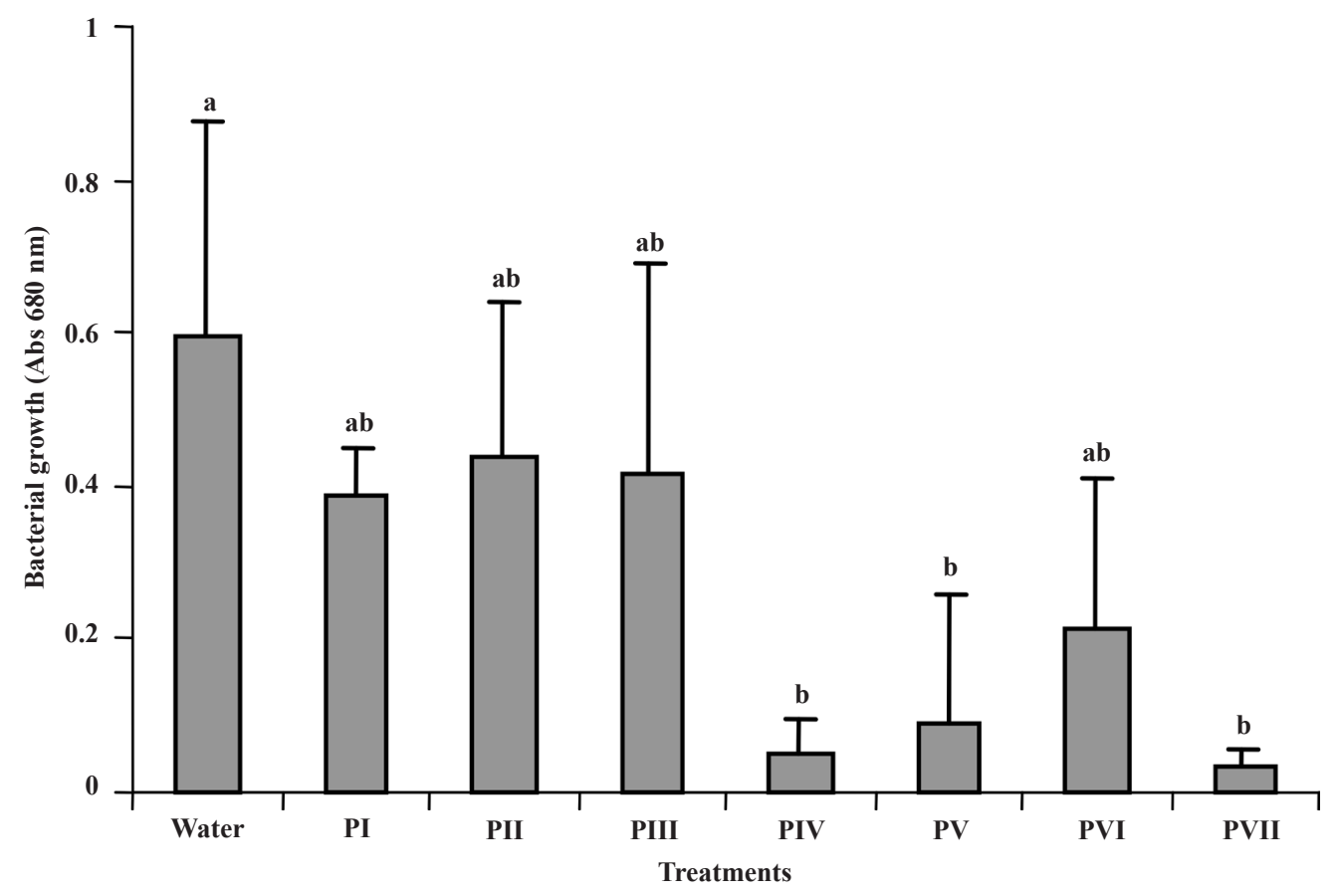

Figure 8. Effect of the pooled fractions (peaks I to VII) of Lentinula edodes (isolate LE 96/22), obtained by anion exchange chromatography, on the in vitro multiplication of Xanthomonas axonopodis pv. passiflorae. Values are the means of five replicates $( \pm \mathrm{SD})$. Means followed by the same letter do not differ according to Tukey's test at 5\%.

edodes culture filtrate did not lose its antibacterial activity against Bacillus subtilis when subjected to $100{ }^{\circ} \mathrm{C}$ for $10 \mathrm{~min}$, but 20,30 and 60 -min heating resulted in 43,72 and $100 \%$ reduction in the activity, respectively (8).

The fractions of aqueous extracts from fruiting bodies of isolate LE 96/22 also exhibited antibiotic activity on $X$. axonopodis multiplication in vitro, since peaks IV, V and VII significantly reduced bacterial growth (Figure 8).

In the present study, peak $\mathrm{V}$ for the aqueous extract from isolate LE 96/22 of basidiomycete L. edodes showed strong antibacterial and antifungal activities. Basidiomycetes as a source of antimicrobial substances have been widely explored. The discovery of strobirulins, produced by the mushroom Strobilurus tenacellus, is one of the most important examples of this type of investigation (24).

The use of fungicides is known to be the main control method for plant diseases but the emergence of resistant fungal isolates, the costs of chemical control and the safety for the environment are important issues to be taken into consideration. Therefore, the search for new products, preferably of low toxicity to humans and to the environment, is necessary.

\section{CONCLUSION}

Aqueous extracts from $L$. edodes isolates have compounds exhibiting antifungal and antibacterial activities against plant pathogens.

\section{ACKNOWLEDGMENTS}

To Dr. Augusto Ferreira da Eira for supplying the L. edodes isolates. This study was supported in part by FAPESP (Fundação de Amparo à Pesquisa do Estado de São Paulo) and by CNPq (Conselho Nacional Científico Tecnológico).

\section{REFERENCES}

1. Bianco, C. Basidiomycetes in relation to antibiosis II. Antibiotic activity of mycelia and culture liquids. Viral Immunology, New Rochelle, v.5, p.267-274, 1981.

2. Deising, H.; Reimann, S.; Pascholati, S.F. Mechanisms and significance of fungicide resistance. Brazilian Journal of Microbiology, São Paulo, v.39, n.2, p.286-297, 2008.

3. Di Piero, R.M.; Pascholati, S.F. Indução de resistência em plantas de pepino contra Colletotrichum lagenarium pela aplicação de extratos de basidiocarpos de Lentinula edodes e de Agaricus blazei. Summa Phytopathologica, Botucatu, v.30, n.2, p. 243-250, 2004.

4. Fischer, I. H.; Rezende, J.A.M. Disease of Passion Flower (Passiflora spp.). Pest Technology, Middlesex, v.2, n.1, p 1-19, 2008.

5. Hatvani, N. Antibacterial effect the culture fluid of Lentinula edodes mycelium grown in submerged liquid culture. International Journal of Antimicrobial Agents, Amsterdam, v. 17, n.1, p.71-74, 2001.

6. Hirasawa, M.; Shouji, N.; Neta, T.; Fukushima, K.; Takada, K. Three kinds of antibacterial substances from Lentinus edodes. International Journal of Antimicrobial Agents, Amsterdam, v.11, n.2, p.151-157, 1999.

7. Hobbs, C. Medicinal value of Lentinula edodes (Berk) Sing (Agricomycetideae): a literature review. International Journal of Medicinal Mushrooms, Redding, v.2, p.287-302, 2000.

8. Ishikawa, N.M.; Kasuya, M.C.M.; Vanetti, M.C.D Antibacterial activity of Lentinula edodes grown in liquid medium. Brazilian Journal of Microbiology, São Paulo, v.32, n.3, p.206-210, 2001.

9. Jong, S.C.; Birmingham, J.M. Medicinal and therapeutic value of the shiitake mushroom. Advances in Applied Microbiology, Maryland Heights, v.39, p.153-184, 1993.

10. Kamida, H.M.; Pascholati, S.F.; Bellato, C.M.; Influência de Saccharomyces cerevisiae na expressão gênica da fenilalanina amônia-liase em tecido de sorgo protegido contra Colletotrichum sublineolum. Summa Phytopathologica, Botucatu, v.26, n.1, p.74-77, 2000.

11. Khan, A.; Hsiang, T. The infection process of Colletotrichum graminicola and relative aggressiveness on four turfgrass species. Canadian Journal Microbiology, Ottawa, v.49, n.7, p.433-442, 2003.

12. Maki, C.S. Respostas fungistáticas de Lentinula edodes sobre Candida albicans e análise da variabilidade intraespecífica. 1999. 109 
f. Dissertação (Mestrado em Genética e Biologia Molecular) - Universidade Estadual de Londrina, Londrina.

13. Malavolta Jr, V.A.; Beriam, L.O.S.; Rodrigues Neto, J. Podridão do fruto, novo sintoma relacionado a Xanthomonas axonopodis pv. passiflorae. Arquivos do Instituto Biológico, São Paulo, v.68, nº 2, p.121-123, 2001.

14. Mizuno, T.; Saito, H.; Nishitoba, T.; Kawagishi, H. Antitumor-active substances from mushrooms. Food Reviews International, Madison, v.11, n.1, p.23-61, 1995.

15. Paccola, E.A.S.; Maki, C.S.; Nobrega, G.M.A.; Paccola-Meirelles, L.D. Antagonistic effect of edible mushroom extract on Candida albicans growth. Brazilian Journal of Microbiology, São Paulo, v.32, n.3, p.176-178, 2001.

16. Pacumbaba, R.P.; Beyl, C.A.; Pacumbaba, R. O. Shiitake mycelial leachate supresses growth of some bacterial species and symptoms of bacterial wilt of tomato and lima bean in vitro. Plant Disease, Saint Paul, v.83, n.1, p.20-23, 1999.

17. Panizzi, R.C.; Fernandes, N.G.; Camardo, M. Doenças do sorgo (Sorghum bicolor). In: Kimati, H.; Amorim, L.; Rezende, J.A.M.; Bergamin Filho, A.; Camargo, L.E.A. (Ed.) Manual de Fitopatologia: doenças das plantas cultivadas. Agronômica Ceres: São Paulo, 2005, v.2, p.597-606.

18. Pascholati, S.F.; Marassato, C.M.; Stangarlin, J.R.; Brand, S.C. Produção de Shiitake em toras de eucalipto. 1.ed. Piracicaba: ESALQ, 2014, 52p.

19. Piccinin, E. Potencial de preparações do cogumelo comestível shiitake (Lentinula edodes) no controle de fitopatógenos fúngicos, bacterianos e virais em sorgo, maracujá e fumo. 2000. 162f. Tese (Doutorado em Fitopatologia)- Escola Superior de Agricultura "Luiz de Queiroz"- Universidade de São Paulo, Piracicaba.

20. Przybylowicz, P.; Donoghue, J. Shiitake growers handbook: the art and science of mushroom cultivation. 1st ed. Dubuque: Kendall/ Hunt, 1990. 217p.

21. Punja, Z.K.; Utkhede R.S. Using fungi and yeasts to manage vegetable crop diseases. Trends Biotechnology, Phyladelphia, v. 21, p.400407, 2003.

22. Sasaki, S.H. Protoplastização de Lentinula edodes e seu antagonismo sobre o vírus VSA e sobre fungos filamentosos. 1997. 69f. Dissertação (Mestrado em Genética e Melhoramento) - Universidade Estadual de Londrina, Londrina.

23. Silva, R. F.; Pascholati, S. F.; Bedendo, I. P. Indução de resistência em plantas de berinjela por Lentinula edodes e Agaricus blazei contra Ralstonia solanacearum: aspectos bioquímicos e biomassa vegetal. Summa Phytopathologica, Botucatu, v.34, n.2, p.137-144, 2008.

24. Ypema, H.L.; Gold, R.E. Kresoxim-methyl: modification of a naturally occurring compound to produce a new fungicide. Plant Disease, Saint Paul, v.83, n.1, p.4-19, 1999.

25. Zuccato, E.; Calamari, D.; Natangelo, M.; Fanelli, R. Presence of therapeutic drugs in the environment. The Lancet, Londres, v.335, p.1789-1790, 2000. 